\title{
SPATIAL ROOT DISTRIBUTION AND WATER UPTAKE OF MAIZE GROWN ON FIELD WITH SUBSOIL COMPACTION
}

\author{
MARGARITA L. HIMMELBAUER ${ }^{1)}$, WILLIBALD LOISKANDL ${ }^{1)}$, SVETLA ROUSSEVA $^{2)}$ \\ ${ }^{1)}$ University of Natural Resources and Applied Life Sciences, Institute of Hydraulics and Rural Water Management, Muthgasse 18, \\ A-1190 Vienna, Austria; Mailto: ml.himmelbauer@boku.ac.at \\ 2)“N. Poushkarov" Institute of Soil Science and Agroecology, Shosse Bankya Street 7, Sofia 1080, Bulgaria.
}

Soil compaction in agricultural areas inhibits plant root growth through increased mechanical resistance, altered water and nutrient supply. The main objective of this study was to evaluate spatial distribution of roots and its effect on water uptake of maize grown on field with subsoil compaction. Two treatments were examined: complex melioration consisting of deep loosening in combination with drainage and control without applied meliorations. Root observations were conducted on vertical and superposed horizontal planes covered with a $2 \mathrm{~cm}$ grid short after silking. Root distributions expressed as index of density and/or dry mass density were estimated down to $1 \mathrm{~m}$ soil depth and with a distance to a plant base. For analysis of root distribution pattern on the horizontal planes, a Variance to Mean Ratio (VMR) test was applied. Soil water monitoring were conducted during the vegetation period. On the vertical planes, root densities were similar in the topsoil of both treatments, but the results were significantly higher in the subsoil of the meliorated one showing deeper allocation of root density. In contrast, the control had more squares with lots of roots (i.e. higher indexes) just at the top- subsoil boundary owing to bunching of roots in macropores. The horizontal planes in the control generally consisted larger areas without visible roots and thus great distances for water and nutrient transmission, especially in the subsoil. The estimated VMR also pointed toward different levels of root clustering. Consequently, an inhibited water extraction from the subsoil in the control, a delay in crop ontogenesis and a less biomass production was established during the observed period.

KEY WORDS: Maize, Soil Compaction, Soil Amelioration, Root Spatial Distribution, Water Uptake.

Margarita L. Himmelbauer, Willibald Loiskandl, Svetla Rousseva: PRIESTOROVÉ ROZDELENIE KOREŇOV A ODBER VODY KOREŇMI KUKURICE V PÔDE SO ZHUTNENOU PODORNIČNOU VRSTVOU. J. Hydrol. Hydromech., 58, 2010, 3; 29 lit., 5 obr. 4 tab.

Zhutnenie pol’nohospodárskej pôdy bráni rastu koreňov; je to spôsobené zvýšeným mechanickým odporom pôdy, a zníženým prítokom vody a živín. Ciel’om tejto štúdie je zhodnotenie priestorovej variability koreňov, ich vplyvu na odber vody koreňmi kukurice na poli so zhutnenou podorničnou vrstvou. Boli hodnotené dva spôsoby obrábania: komplexná meliorácia pozostávajúca z hlbokého podrývania v kombinácii s drenážou a obrábanie (kontrola) bez melioračných zásahov. Identifikácia rozdelenia koreňov bola vykonaná vo vertikálnych a horizontálnych rovinách s 2 -cm sietou, krátko po metaní. Rozdelenie koreňov bolo vyjadrené ako index hustoty alebo ako hustota suchej biomasy koreňov do híbky $1 \mathrm{~m}$; v horizontálnom smere až k susedným rastlinám. Bol použitý test „Variance to Mean Ratio” (VMR) na určenie rozdelenia koreňov $\mathrm{v}$ horizontálnom smere počas vegetačného obdobia. Hustota koreňov vrchnej vrstvy pôdy vo vertikálnej rovine bola podobná pre obidve varianty, ale pre meliorovanú pôdu boli hodnoty hustoty koreňov v podloží podstatne vyššie a korene zasahovali hlbšie. Ako protiklad, na kontrolnom pozemku bolo viac štvorcov s mnohými koreňmi (t.j. vyššie indexy) práve na hranici orničnej a podorničnej vrstvy, pre enormný rast koreňov $\mathrm{v}$ makropóroch. $\mathrm{V}$ horizontálnej rovine tento kontrolný pozemok obsahoval vel'ké oblasti bez viditel'ných koreňov, a to znamená vel'ké vzdialenosti pre prenos vody a živín v podorničnej vrstve. Výsledky aplikácie VMR naznačujú tiež rozdielne úrovne zhlukov koreňov. Z toho vyplýva znížený odber vody koreňmi rastlín na kontrolnom pozemku, ako aj pomalšia ontogenéza a nižšia produkcia biomasy, ktorá bola identifikovaná počas sledovaného obdobia.

KLÚČOVÉ SLOVÁ: kukurica, meliorácia pôdy, priestorové rozdelenie koreňov, odber vody koreňmi. 


\section{Introduction}

Soil compaction, occurring naturally or a consequence of inappropriate land management, is a problem often established in agricultural areas. It can deteriorate structure, porosity and pore-size distribution, and decrease water permeability in soil (Horn et al., 2000). Many cultivated soils in Bulgaria are compacted, characterized by poor structure, and about $5 \%$ of them are prone to waterlogging (Dilkova et al., 1998). In such soils, roots suffer due to increased mechanical resistance against root penetration, inhibited water, nutrient and oxygen supply. The negative impact depends on climate conditions as well as on particular root system characteristics.

For efficient uptake of water by plants, the water "availability "as well as its "accessibility" to the roots is critical (Droogers et al., 1997). Water "availability" refers to soil ability to supply roots with water at a sufficient rate and is mainly a function of soil hydraulic characteristics. The water "accessibility", however, highly depends on root system extension and spatial distribution of roots. Root elongation is influenced by penetration resistance of the soil and thus by its bulk density, structure and pore system. In compacted soils, roots are often confined into large pores and are less efficient in uptake due to high intra-root completion. In addition, an insufficient supply of water and nutrients occurs owing to low hydraulic conductivity and diffusion rate in compacted soil spots. As a result of root clustering, water cannot be taken up at a rate useful for plants compared to soils with equivalent but uniformly distributed roots (Baldwin et al., 1972; Tardieu at al., 1992; Amato and Ritchie, 2002). Droogers et al. (1997) extended this approach, showing that not only extreme compaction but also different aggregates structure of soil, formed by various land management practices, leads to root grouping and influenced the uptake of water. Besides the root density parameter widely used for modeling and simulation of root uptake at a field scale (e.g. Novak, 2003), the root spatial distribution (rooting pattern) appears to be also important for water and nutrient acquisition by plants. This concept provides a basis for novel modeling of root uptake, however fitting data for validation is really still scarce (Lipiec et al., 2003; Pardo et al., 2000).

The main objective of this study was to assess root spatial distribution and water uptake of maize grown on field with subsoil compaction. A specific task was to examine the effect of amelioration practices against subsoil compaction on soil characteristics and thus on root development and crop productivity. Hydro-technical and ameliorative measures against soil compaction have been seldom applied, since they are costly and their long-term positive effects are arguable.

\section{Material and methods}

\section{Climate and soil conditions}

The experiments were conducted on a research field of the "N. Pushkarov" Institute of Soil Science and Agro-ecology in Thracian lowland, semi-arid area of South Bulgaria. The climate is continentalMediterranean with a mean annual temperature of $12^{\circ} \mathrm{C}$ and a long-term annual precipitation of about $600 \mathrm{~mm}$. A major rainfall maximum has been observed at the end of autumn -beginning of winter, a minimum precipitation- in late summer along with long periods of drought (Georgieva et al., 2007). The precipitation sums during the winter are often insufficient to complete even the lower limit of the readily available water for plants (Koleva and Alexandrov, 2008).

The soil is fine textured Dystric Planosol (PLd, FAO soil classification) having elluvial-illuvial deep profile with high degree of textural differentiation (Boyadgiev, 1994; Dilkova et al., 1998). This textural differentiation, derived from the difference in clay content between two soil horizons, leads to compaction and low permeability for water of the subsoil. As a result, the soil is prone to surface waterlogging in early springs.

\section{Experimental setup, soil and root observations}

Soil meliorations using different hydro-technical and ameliorative methods to increase water permeability of the waterlogged soil were applied a few years ago following Shopski et al. (1998). In this study two main treatments were examined: deep loosening in combination with mole drainage and a control without ameliorations applied. The combined soil amelioration consisted of loosened soil zones to a depth of $60 \mathrm{~cm}$ and mole channels with a distance between furrows of $11 \mathrm{~m}$. A durability of the channels depends on the soil, the climate and the local land management, but the positive effect 
on soil water permeability generally disappears in a course of ten years after the treatment.

Experimental plots of $90 \mathrm{~m}^{2}$ were planted in the beginning of May with maize (Zea mays L. var. "Kneza"). Herbicides were applied shortly after planting, rest weeds were removed mechanically or hand pulled. Else, the both plots were managed according to the common local farming using mouldboard ploughing to about $30 \mathrm{~cm}$ depth.

A series of soil physical and chemical characteristics were measured in advance to the experiment taking disturbed and undisturbed soil samples down to $1 \mathrm{~m}$ depth in both plots, i.e. particle size distribution, particle and bulk density, porosity, hydraulic conductivity at saturation, plant available water, $\mathrm{pH}$, humus content, carbonates. For evaluation of the gravimetric soil water content, soil samples down to $1 \mathrm{~m}$ depth were taken continuously throughout observation period. Plant growth and development stages of maize were monitored, biomass production was measured at harvest.

Root spatial distribution was examined using soil profile method shortly after silking maize stage (female flowering) when root systems are fully developed reaching their largest extension. First, representative areas completely free of weeds, having a regular crop spacing and development were selected. A trench was dug perpendicular to the crop rows to about $1 \mathrm{~m}$ soil depth. A profile $(100 \times 72 \mathrm{~cm})$ covering one maize row and two half "between rows" distances left and right to the row was carefully smoothed. A few millimeters of roots was made visible from the adjacent soil using air and water under pressure in addition to hand tools. Next the profile was covered with a fine grid mesh of $2 \times 2 \mathrm{~cm}$. Root contacts were counted and indexes of density were introduced, accounting for a presence and an absence of fine and coarse roots in each square following Tardieu (1988a). The indexes of root density equaled to $0-$ absence of roots, 2 - one thin root visible, 4 - many thin roots visible, 8 - two and more thick roots $>2 \mathrm{~mm}$ and thin branches visible. The indexes were related to root mass density per volume of soil taking small soil monoliths (cubes) with a face one mesh square from different depths and positions. The roots were washed out, their dry mass was measured, and thus the root mass density distribution down the soil profile was estimated indirectly. Two profiles (replications) were prepared in the same trench dug a few $\mathrm{cm}$ apart resembling a distance between single plants. Three horizontal planes $(40 \times 72 \mathrm{~cm})$, covering the same row and the two half "between rows" distances, were dug on superposed depths intersecting the rooting volume in the middle of the topsoil $\left(\mathrm{A}_{1} \mathrm{~A}_{2}\right.$ horizon) at $13 \mathrm{~cm}$, at the bottom of the topsoil at about $25 \mathrm{~cm}$, and in the middle of the compacted subsoil (B horizon) at about $50 \mathrm{~cm}$ depth. The horizontal planes were prepared in a similar way as the vertical ones. The root density index here equaled the number of roots counts in each square.

\section{Data analyses}

Root density distributions expressed as indexes of density per square, percentage of squares consisting roots and root mass per volume of soil were calculated and plotted over the soil depth and with a distance to the crop row. Estimated results were compared with the measured soil parameters. Summary statistics, analysis of variance, and correlation analyses were conducted to find out the relations between different root, and soil parameters. For analysis of root distribution (pattern) on the horizontal planes, an additional Variance to Mean Ratio (VMR) test, called also index of dispersion, was used. The VMR test is proposed to characterize spatial distribution of points (Grieg Smith, 1983). The point distribution in a certain neighborhood may represent some interactions in-between, i.e. the points may occur in clusters, or there is a lack of interactions and the point distribution is completely random, or following deterministic pattern, thus the points are regularly distributed within the definite area. If the point distribution is random, it can be described by a Poisson process, where the variance and the mean values are equal and the approximated Variance to Mean Ratio is close to 1. VMR values larger than 1 point to existence of clusters, i.e. grouped or cluster distribution pattern which is mainly associated with a Negative binomial or Neyman type A theoretical distributions. VMR values below 1 suggest more uniform (regular) point distribution (Wulfsohn et al., 1996). In this study, the VMR was estimated for the root counts observed on the all horizontal planes in both treatments.

\section{Results and discussions}

\section{Soil properties}

Essential soil characteristics are presented in Tab. 1. The soil is classified as clay loam in the topsoil and clay in the subsoil. The topsoil is acidified due to carbonate leaching down the soil profile. 
Bulk density (BD) is a commonly used indicator for soil compaction (Bennie, 1996; Hakansson and Lipiec, 2000). BD values optimal for plant growth vary for different soils, but roots rarely enter soil if BD exceeds $1.6-1.7 \mathrm{~g} \mathrm{~cm}^{-3}$ (Russel, 1980). In this study, all BD measurements at field capacity were relatively high, but below the cited threshold value approximating $1.45 \mathrm{~g} \mathrm{~cm}^{-3}$ for the a good portion of the rooting depth in both plots (Tab. 1). However, the BD rose rapidly with the soil getting drier in the course of time. At the time of root sampling, the BD's reached a maximum of $1.64 \mathrm{~g} \mathrm{~cm}^{-3}$ at $30 \mathrm{~cm}$ depth (the topsoil- subsoil boundary) in the control plot. The BD's down to $50 \mathrm{~cm}$ depth in the meliorated plot did not change greatly compared to the values measured in spring and lay between 1.36 and $1.54 \mathrm{~g} \mathrm{~cm}^{-3}$ (data not shown). This seemingly was a subsequent effect of the hydrotechnical ameliorations against soil compaction.

$\mathrm{T} \mathrm{a} \mathrm{b} \mathrm{le} \mathrm{1.} \mathrm{Major} \mathrm{physical} \mathrm{and} \mathrm{chemical} \mathrm{properties} \mathrm{of} \mathrm{the} \mathrm{soil} \mathrm{in} \mathrm{the} \mathrm{experimental} \mathrm{field.}$

T a b u l' k a 1. Najdôležitejšie fyzikálne a chemické vlastnosti pôdy na experimentálnom poli.

\begin{tabular}{|c|c|c|c|c|c|c|c|c|c|c|c|c|c|c|c|}
\hline \multicolumn{5}{|c|}{ Dystric planosol } & \multirow{2}{*}{ 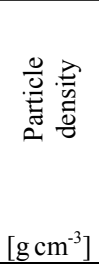 } & \multirow{2}{*}{ 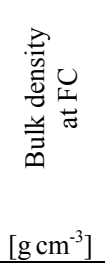 } & \multirow{2}{*}{ 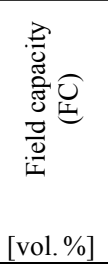 } & \multirow{2}{*}{ 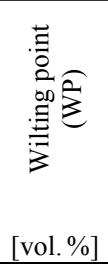 } & \multirow{2}{*}{ 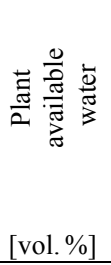 } & \multirow{2}{*}{ 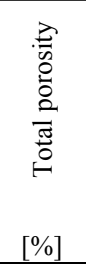 } & \multirow{2}{*}{ 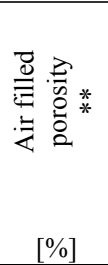 } & \multirow{2}{*}{ 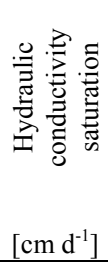 } & \multirow{2}{*}{ 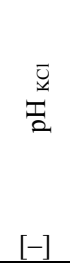 } & \multirow{2}{*}{$\begin{array}{c}\text { 节 } \\
\text { 全 } \\
{[\%]}\end{array}$} & \multirow{2}{*}{ 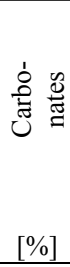 } \\
\hline Horizon & $\begin{array}{l}\text { Depth } \\
{[\mathrm{cm}]}\end{array}$ & $\begin{array}{c}\text { Clay } \\
{[\%]}\end{array}$ & $\begin{array}{l}\text { Silt } \\
{[\%]}\end{array}$ & $\begin{array}{r}\text { Sand } \\
{[\%]}\end{array}$ & & & & & & & & & & & \\
\hline \multicolumn{16}{|c|}{ Non-meliorated plot } \\
\hline $\mathrm{A}_{1} \mathrm{~A}_{2}(0-22)$ & $10-15$ & 27.1 & 42.7 & 30.2 & 2.63 & 1.46 & 42.08 & 13.80 & 28.28 & 44.49 & 2.41 & 105.5 & 4.00 & 1.88 & 0.00 \\
\hline$B_{1(t)}(22-42)$ & $35-40$ & 40.2 & 32.3 & 27.5 & 2.68 & 1.46 & 40.57 & 20.54 & 20.03 & 45.52 & 4.95 & 0.00 & 4.05 & 1.50 & 0.00 \\
\hline $\mathrm{B}_{2(\mathrm{t})}(42-72)$ & $50-55$ & 48.0 & 30.5 & 21.5 & 2.68 & 1.45 & 39.59 & 17.41 & 22.17 & 45.90 & 6.31 & 0.00 & 4.80 & 1.32 & 0.00 \\
\hline $\mathrm{B}_{3(\mathrm{t})}(72-95)$ & $80-85$ & 44.9 & 31.2 & 23.9 & 2.70 & 1.47 & 39.23 & 19.37 & 19.86 & 45.56 & 6.32 & 0.36 & 6.00 & 0.74 & 0.00 \\
\hline \multicolumn{16}{|c|}{ Meliorated plot } \\
\hline $\mathrm{A}_{1} \mathrm{~A}_{2}(0-28)$ & $10-15$ & 32.8 & 44.9 & 22.3 & 2.56 & 1.35 & 34.48 & 13.57 & 20.91 & 47.27 & 12.79 & 42.03 & 3.50 & 1.74 & 0.00 \\
\hline $\mathrm{B}_{1(\mathrm{t})}(28-55)$ & $40-45$ & 53.8 & 29.9 & 16.3 & 2.73 & 1.47 & 42.14 & 30.30 & 14.76 & 46.15 & 4.01 & 5.04 & 3.80 & 1.00 & 0.00 \\
\hline $\mathrm{B}_{2(\mathrm{t})}(55-78)$ & $65-70$ & 53.1 & 26.7 & 20.2 & 2.74 & 1.45 & 42.64 & 31.40 & 16.31 & 47.08 & 4.44 & 2.01 & 4.60 & 0.90 & 0.00 \\
\hline $\mathrm{B}_{3(\mathrm{t})}(78-100)$ & $85-90$ & 51.8 & 33.9 & 14.3 & 2.79 & 1.53 & 41.46 & 29.27 & 15.87 & 45.16 & 3.70 & 10.05 & 5.60 & 0.65 & 0.00 \\
\hline
\end{tabular}

*Texture fractions: Clay $(<0.002 \mathrm{~mm})$, Silt $(0.002-0.05 \mathrm{~mm})$, Sand $(0.05-2 \mathrm{~mm})$.

*Klasifikácia textúry: íl $(<0.002 \mathrm{~mm})$, prach $(0.002-0.05 \mathrm{~mm})$, piesok $(0.05-2 \mathrm{~mm})$.

**Air filled porosity at field capacity is calculated after Vomocil (1965) as a difference between the total porosity and the volumetric water content at FC

**Podiel pórov zaplnených vzduchom pri pol'nej vodnej kapacite pôdy, bol vypočítaný podl’a Vomocila (1965), ako rozdiel medzi pórovitost'ou a vlhkost'ou pri FC.

Surprisingly, the water content assessed at FC level was higher in the topsoil of the nonmeliorated than in the meliorated one, and the WPwater contents were lower. Correspondingly, more plant available water (Allen et al., 1998) was estimated for the entire rooting depth in the control.

The estimated total porosity was a bit higher in the meliorated plot, but the differences to the control were insignificant. Air-filled porosity represents the pore space filled with air after the soil has been drained and includes pores mainly larger than $0.05 \mathrm{~mm}$. As critical limits for air-filled porosity, below which root growth and uptake are inhibited, are accepted values of $10 \%$ (volumetric) for clay and $15 \%$ for sandy soils (Arvidsson, 1999; Hakansson and Lipiec, 2000). In this study, the air-filled porosity at field capacity (FC) was calculated after
Vomocil (1965). The estimates were below the critical limits except of the meliorated topsoil, suggesting insufficient amount of (macro-)pores in the large part of the rooting zone (Tab. 1). The minimum of $2.4 \%$ was found in the topsoil of the nonmeliorated plot (control). Therefore, even at optimal soil water conditions the plant roots here will be at a risk of suffering for aeration. In addition, only minor differences between the air-filled porosity measurements in the subsoil of the two plots were established. At the same time, the hydraulic conductivity measured at saturation was higher in the subsoil of the meliorated than the nonmeliorated plot, but the variation between single measurements was high. No significant differences in the rest of the evaluated soil parameters between non-meliorated and meliorated plots were found. 


\section{Root density distribution}

At the time of root observation, the maize root systems already reached a soil depth of $1 \mathrm{~m}$ (Fig. 1). A high variability in root density (indexes) was observed between the single profiles (replications) in both treatments. Between the treatments, however, the measured indexes and the shape of distribution curves down the soil profile did not differ significantly $(\mathrm{P}<0.05$, ANOVA). The highest den- sity index for the both plots was measured in the top $30 \mathrm{~cm}$ depth (topsoil). Below this depth, the root density in the control decreased gradually resembling an exponential curve typically observed for field grown crops (Himmelbauer et al., 2008). In the meliorated plot, however, the density index values were comparable between 30 and $60 \mathrm{~cm}$ soil depth (i.e. the melioration depth), and downwards decreased.
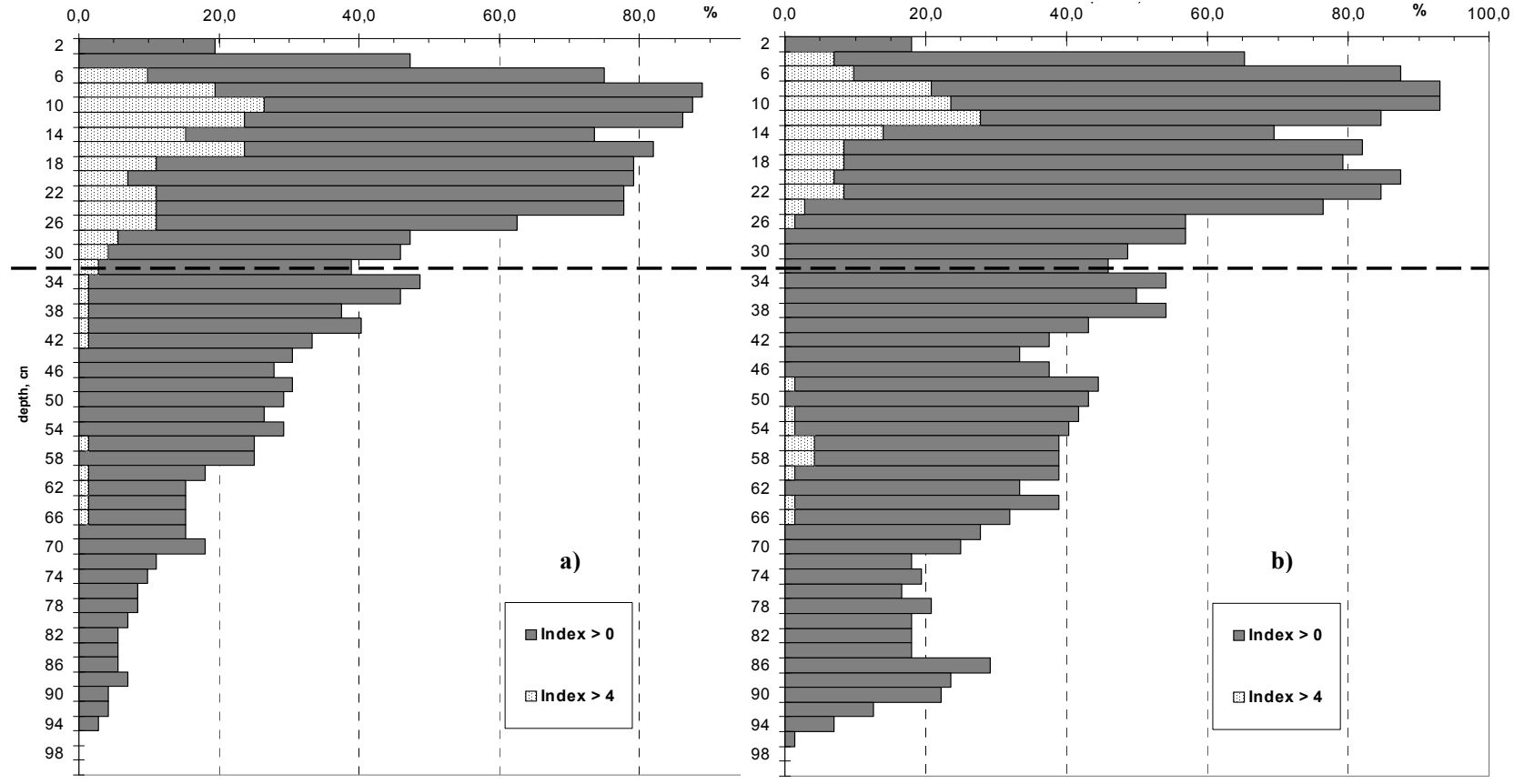

Fig. 1. Percent distribution of squares consisting at least one root (index $>0$ ) and with lots of roots (index $>4$ ) averaged for the two profiles in the a) non-meliorated and b) meliorated plots.

Obr. 1. Percentuálne rozdelenie štvorčekov obsahujúcich aspoň jeden koreň (index $>0$ ) a štvorčekov s viacerými koreňmi (index $>4$ ) spriemerované pre dva profily; a) nemeliorovaný variant, b) meliorovaný variant.

As can be seen on the Fig. 1, between 60 and $90 \%$ of the squares in the topsoil consisted at least one visible root (i.e. proportion of squares with index $>0$ ), with small differences between the treatments. Close to the top-subsoil boundary, the proportion of squares with index $>0$ was considerably higher in the meliorated than in the nonmeliorated plot, showing more homogeneous distribution of roots there. In the subsoil of the meliorated plot $50 \%$ "full" squares were found in the upper $30 \mathrm{~cm}$ and $20 \%$ underneath at $60 \mathrm{~cm}$ depth, against $30 \%$ and $10 \%$ in the control, respectively. Hence, the effect of the former meliorations with deep loosening to $60 \mathrm{~cm}$ depth on the root distribution was obvious. On the other site, the nonmeliorated plot had more squares consisting plenty of roots (index $>4$ ), especially close to the topsubsoil boundary. Root growth in compacted soil is not completely restricted when macrospores or cracks are present, and a preferential root growth occurs in these pores (Laboski et al., 1998; Bingham and Bengough, 2003). In this study, the observed high root density indexes were a clear indication of root grouping into macropores crossing the top- and compacted subsoil. The results of the root mass density averaged for the two profiles (replications) are shown in Fig. 2. Values between 0.10 and $0.70 \mathrm{mg} \mathrm{cm}^{-3}$ were estimated for the topsoil with no considerable difference between the treatments $(P<0.05$, ANOVA). Between $30 \mathrm{~cm}$ (topsoil) and $60 \mathrm{~cm}$ (subsoil), the values in the meliorated plot were close to $0.20 \mathrm{mg} \mathrm{cm}^{-3}$, and ap- 
proximated the half of the root density in the nonmeliorated one. Below this depth, the root density in both plots decreased gradually to about $0.03 \mathrm{mg} \mathrm{cm}^{-3}$. Spatial variations in the soil bulk density along with the soil water content changes allowed roots to find paths to cross the compacted layer. In the control, about $28 \%$ of the total root mass was found within the subsoil and $72 \%$ in top. In contrast, the corresponding values in the meliorated plot were $36 \%$ against $64 \%$ showing apparently deeper allocation of the maize root mass at the time of observation.


Fig. 2. Root density distribution down the soil profile expressed as root dry mass density $\left[\mathrm{mg} \mathrm{cm}^{-3}\right]$ for a) non-meliorated and b) meliorated plots. Horizontal bars represent standard deviations.

Obr. 2. Rozdelenie hustoty koreňov vo vertikálnom smere, vyjadrené ako hustota suchej masy koreňov [mg $\left.\mathrm{cm}^{-3}\right]$ pre: a) nemeliorovaný variant, b) meliorovaný variant. Horizontálne bodkované čiary reprezentujú štandardné odchýlky.

Concerning the horizontal allocation of root density, a concentration of roots near the maize row was observed in the topsoil, more evident in the meliorated plot than in the non-melioration one. In the subsoil, more homogeneous distribution with respect to the plant base was observed in both treatments: the density distribution shifted to the inter-rows, the differences to the row position were smaller and variability got higher.

On the horizontal planes (Fig. 3), the proportions of the squares where at least one root contact was observed (index $>0$ ) were between 60 to $90 \%$ at $13 \mathrm{~cm}$ depth in the meliorated plot, demonstrating more homogeneous distribution with close distances between single root axes. The average value for the $25 \mathrm{~cm}$ plane was $56.4 \%$ and $39.3 \%$ for the lowest one at $50 \mathrm{~cm}$ depth. The corresponding val- ues for the three superposed planes in the control were $63.3 \%, 31.1 \%$ and $15.6 \%$, respectively.

Some discrepancies in the root density results between the vertical and the horizontal maps were observed. They most probably resulted from the preferentially horizontal direction of the seminal roots in the topsoil and vertical in the subsoil as well as due to root branching pattern of maize (Koedjikov, 1975). Thus, the results of the vertical mapping seemed to be underestimated for the areas with more horizontal root growth and lack of branching in the topsoil, and just the opposite phenomenon happened underneath. Similar phenomenon was reported also by Chopart and Siband (1999).

Different tests have been proposed for analysis of spatial root distribution (pattern), i.e. theoretical distributions such as Poisson, Negative binomial or 

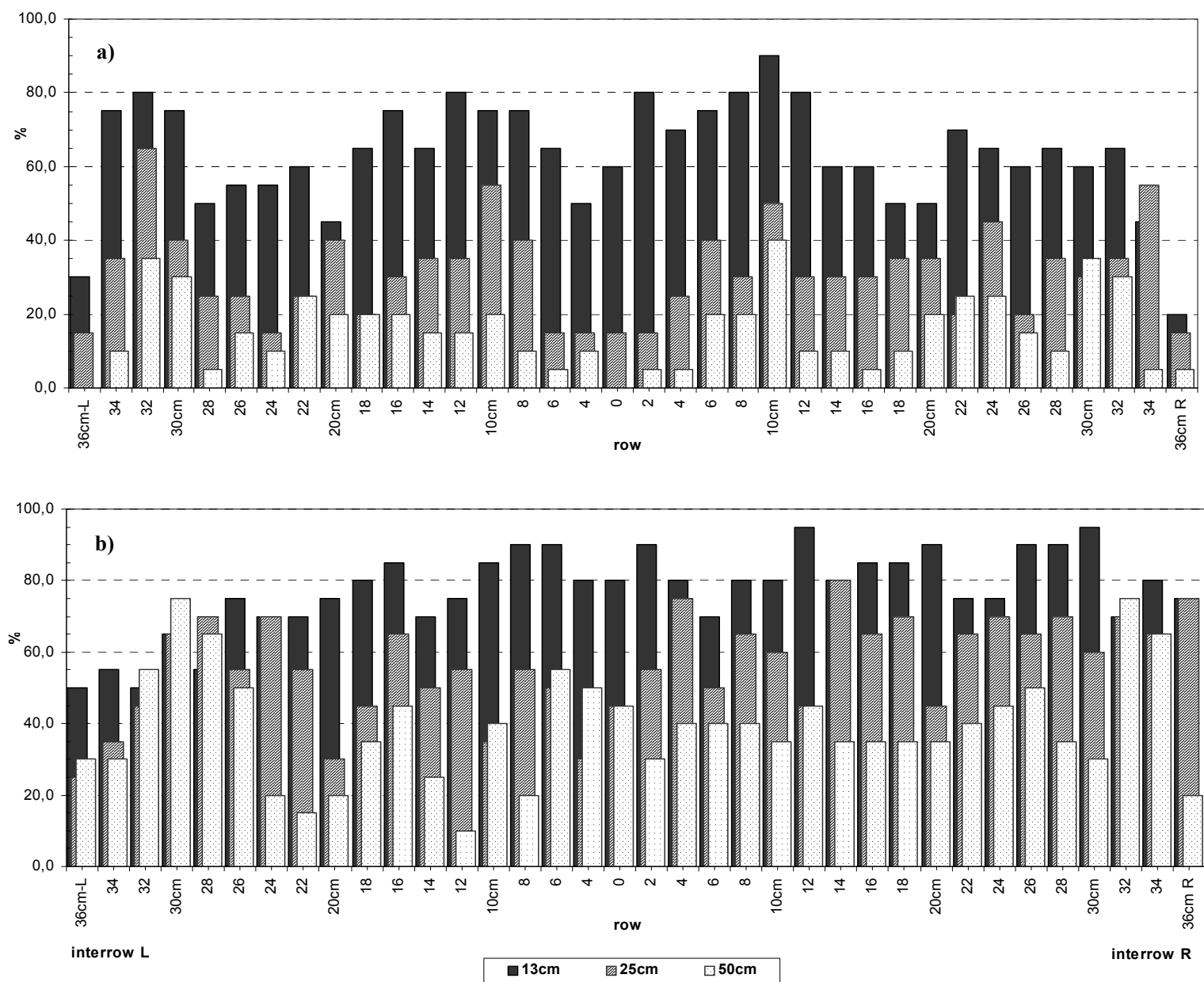

Fig. 3. Percent distribution of squares consisting at least one root (index $>0$ ) observed on the three superposed horizontal planes at $13 \mathrm{~cm}, 25 \mathrm{~cm}$ and $50 \mathrm{~cm}$ in a) non-meliorated and b) meliorated plots.

Obr. 3. Percentuálne rozdelenie štvorčekov obsahujúcich aspoň jeden koreň (index $>0$ ), pozorované $\mathrm{v}$ troch superponovaných horizontálnych rovinách v híbke 13, 25 a $50 \mathrm{~cm}$; a) nemeliorovaný variant, b) meliorovaný variant.

the Neyman type A (Baldwin et al., 1972; Wulfsohn et al., 1996), a nearest neighbor test, a spatial autocorrelation test (Tardieu, 1988b), a skewness test (Rogers, 1974), etc. The Variance to Mean Ratio (VMR) test has been proposed for ecological studies (Grieg Smith, 1983). Reported scales of the application of the VMR test (the chosen size of the tested unit area) vary between different studies. According to Baddeley (2008), the power of the VMR test depends on the size and falls to zero for squares which are either very large or very small. Nevertheless, it gives an clear indication of important clustering processes occurred in soil. Baldwin et al. (1972) coupled it to diffusion coefficients of certain nutrients in soil and applied the test at a centimeter scale. Enlarging the quadrates to a decimeter scale, Tardieu (1988b) came to the conclusion that their size will not significantly affect the VMRatios in soils with relatively small structural impediments. This statement was confirmed by Wulfsonh et al. (1996).

In this study, the VMR test was applied for the three superposed horizontal planes starting with the squares size of $2 \mathrm{~cm}$ (the mesh grid size) and increasing it to $10 \mathrm{~cm}$ in both trials. The square sizes corresponded to the dimension of soil aggregation and compacted clods observed in situ. The mean number of the root counts observed in each square (the root index on the horizontal planes) and the corresponding variances were calculated. Then the ratios between them, the VMR values were estimated for each depth position and treatment. $T$-test was used to compare the calculated VMR with the theoretical value of 1 . The results are presented in Fig. 4 and Tab. 2. 


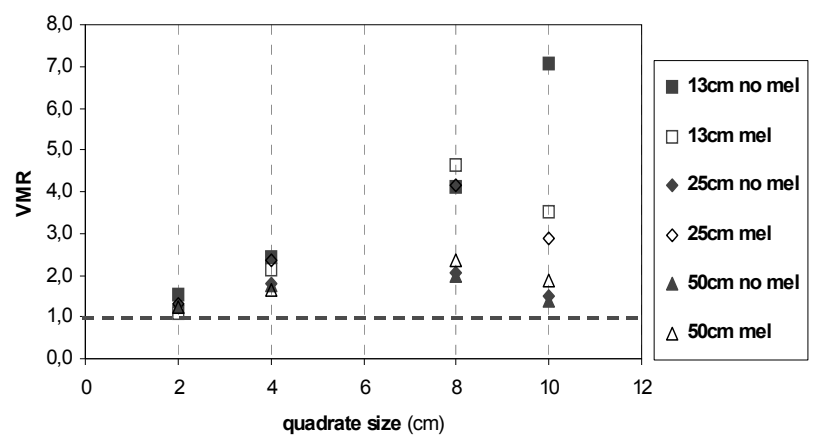

Fig. 4. Results of the Variance to Mean Ratio (VMR) test applied for the root counts per square of $2,4,8$ and $10 \mathrm{~cm}$ size for the three superposed horizontal planes in non-meliorated (no mel) and meliorated (mel) plots.

Obr. 4. Výsledky testu „Variance to Mean Ratio” (VMR), aplikované na počty koreňov vo štvorčeku s vel'kost'ou strany 2, 4, 8 a $10 \mathrm{~cm}$ pre tri superponované horizontálne roviny v híbke 13, 25 a $50 \mathrm{~cm}$; a) nemeliorovaný variant, b) meliorovaný variant.

The obtained results showed that the spatial patterns of roots did not follow a regular spatial distribution (assumed in the majority models of water uptake) either in the meliorated or in the nonmeliorated plot. Just the VMR value at $2 \mathrm{~cm}$ scale (square size) at the $13 \mathrm{~cm}$ depth in the meliorated plot equaled 1.0, suggesting a non cluster but random type of root distribution (Tab. 2). In addition, only at this depth statistically significant differences in the root counts number were established between the meliorated and non-meliorated plot. With increasing the square size to $8 \mathrm{~cm}$, the VMR values rose rapidly larger than 1 , stronger in the ploughed topsoil layer than below it. These scales of the testing most probably coincidence with the size of the soil aggregates and clods in the field. At a decimeter scale $(10 \mathrm{~cm})$, the VMR values dropped at all positions except of the topsoil in the control. In this case, the quadrates probably oversized the dimension of the soil clods. Surprisingly, in most cases the subsoil had lower VMR values compared to the topsoil, although that the visual examination in situ showed large structural barriers and root clustering at a transit to and within the compacted subsoil.

\section{Soil water monitoring}

Changes of the soil water content down the soil profile measured gravimetrically during the vegetation period are shown in Fig. 5. The values varied more rapidly and higher in the topsoil $(0-30 \mathrm{~cm})$ than in the subsoil, due to fluctuations in precipita- tion, temperature and evaporation as well as due to the foremost root uptake, especially in the beginning of the growing period. End of June, when maize approached the end of the vegetative stage in the meliorated plot, an apparent decrease in the water content occurred also in the subsoil. In the control, the subsoil- water content values were still high. The maize plants just came to the 9 to 12 leaf stage and obviously did not extract lots of water from the subsoil. Until end of July matching the crop stage of silking in the meliorated plot, the soil in the $0-50 \mathrm{~cm}$ depth rapidly dried due to the enhanced root water uptake. There were two dry periods observed: in the middle of July and in August. Coming to harvest, the soil water content further decreased in all soil layers in both plots. In the control, the topsoil-water was almost depleted, while the subsoil remained much wetter than in the meliorated plot. The water uptake by root was obviously still restricted to the topsoil with low activity down the soil profile, although the high amount of plant available water estimated. This suggested some limitations for water uptake by the maize roots. In the meliorated plot, the subsoil water content depleted further and greater than in the control. This was attributed to the faster growth and the more extensive root water uptake there.

In spring, the estimated soil water storage in $\mathrm{mm}$ was close to the field capacity level and after that it decreased more or less steadily(data not shown). As the plants come to silking, the water storage approached the wilting point in both treatments and at harvest it fell below the WP level, first in the meliorated plot and thereafter in the control. In general, the available water reserves in the meliorated depleted more rapidly than those in the control.

Maize in the meliorated and non-meliorated plots developed differently. As it was also reported by Bingham and Bengough (2003), the growth of crop shoots was reduced when part of the root system was in compacted soil, although some compensatory adjustments in root growth. The plants in the meliorated plot were observed to grow more rapidly reaching the next growth stage one to two weeks earlier than those in the control. Accordingly, higher above-ground biomass production was found there. Crop parameters measured at root sampling and at harvest are presented in Tab. 3. The maize plants in the meliorated plots were much higher and developed twice as spasing before leaf area and biomass. 
$\mathrm{T} \mathrm{a} \mathrm{b} 1 \mathrm{e} 2$. Analyses of spatial arrangement of the root counts (indexes) on the tree superposed horizontal planes in the nonmeliorated and meliorated plots.

$\mathrm{T}$ a b u l' k a 2. Analýza priestorového usporiadania počtu koreňov (indexy) v troch superponovaných horizontálnych rovinách meliorovanej a nemeliorovanej pôdy.

\begin{tabular}{|c|c|c|c|c|c|c|c|c|c|}
\hline \multirow[b]{3}{*}{ Depth } & \multirow[b]{3}{*}{$\mathrm{Nr}$ squares } & \multicolumn{8}{|c|}{ Root counts per square } \\
\hline & & \multicolumn{3}{|c|}{ No melioration $^{\dagger}$} & \multirow[b]{2}{*}{ VMR } & \multirow[b]{2}{*}{ Mean } & \multicolumn{2}{|c|}{ Melioration } & \multirow[b]{2}{*}{ VMR } \\
\hline & & Mean & median & Variance & & & median & Variance & \\
\hline & Square size & & $2 \times 2 \mathrm{~cm}$ & & & & & & \\
\hline $13 \mathrm{~cm}$ & 720 & $1.33 \mathrm{~A}$ & 1 & $2.05 \mathrm{a}$ & $1.535^{* * *}$ & $1.93 \mathrm{~B}$ & 2 & $2.12 \mathrm{~b}$ & 1.101 \\
\hline $26 \mathrm{~cm}$ & 720 & $0.43 \mathrm{~A}$ & 0 & $0.55 \mathrm{a}$ & $1.271 * * *$ & $1.06 \mathrm{~A}$ & 1 & $1.37 \mathrm{a}$ & $1.298 * * *$ \\
\hline \multirow[t]{2}{*}{$50 \mathrm{~cm}$} & 720 & $0.19 \mathrm{~A}$ & 0 & $0.23 \mathrm{a}$ & $1.223^{* * *}$ & $0.58 \mathrm{~A}$ & 0 & $0.72 \mathrm{a}$ & $1.235^{* * *}$ \\
\hline & Square size & & $4 \times 4 \mathrm{~cm}$ & & & & & & \\
\hline $13 \mathrm{~cm}$ & 180 & $5.06 \mathrm{~A}$ & 5 & $12.29 \mathrm{a}$ & $2.429 * * *$ & $7.71 \mathrm{~B}$ & 7 & $16.54 \mathrm{~b}$ & $2.147 * * *$ \\
\hline $26 \mathrm{~cm}$ & 180 & $1.73 \mathrm{~A}$ & 1 & $3.12 \mathrm{a}$ & $1.803 * * *$ & $4.23 \mathrm{~A}$ & 4 & $9.93 \mathrm{a}$ & $2.347 * * *$ \\
\hline \multirow[t]{2}{*}{$50 \mathrm{~cm}$} & 180 & $0.76 \mathrm{~A}$ & 0 & $1.34 \mathrm{a}$ & $1.769^{* * *}$ & $2.32 \mathrm{~A}$ & 2 & $3.81 \mathrm{a}$ & $1.639 * * *$ \\
\hline & Square size & & $8 \times 8 \mathrm{~cm}$ & & & & & & \\
\hline $13 \mathrm{~cm}$ & 45 & $20.13 \mathrm{~A}$ & 17 & $82.71 \mathrm{a}$ & $4.108 * * *$ & $30.78 \mathrm{~A}$ & 27 & $142.60 \mathrm{a}$ & $4.634 * * *$ \\
\hline $26 \mathrm{~cm}$ & 45 & $6.89 \mathrm{~A}$ & 7 & $14.06 \mathrm{a}$ & $2.04 * * *$ & $16.96 \mathrm{~A}$ & 17 & $70.63 \mathrm{a}$ & $4.166^{* * *}$ \\
\hline \multirow[t]{2}{*}{$50 \mathrm{~cm}$} & 45 & $3.00 \mathrm{~A}$ & 3 & $6.00 \mathrm{a}$ & $2.00 * * *$ & $9.27 \mathrm{~A}$ & 9 & $21.65 \mathrm{a}$ & $2.337 * * *$ \\
\hline & Square size & & $10 \times 10 \mathrm{~cm}$ & & & & & & \\
\hline $13 \mathrm{~cm}$ & 24 & $35.33 \mathrm{~A}$ & 31 & $249.4 \mathrm{a}$ & $7.057 * * *$ & $50.42 \mathrm{~A}$ & 49 & $177.80 \mathrm{a}$ & $3.527 * * *$ \\
\hline $26 \mathrm{~cm}$ & 24 & $10.50 \mathrm{~A}$ & 10 & $15.65 \mathrm{a}$ & $1.491 *$ & $25.96 \mathrm{~A}$ & 27 & $74.91 \mathrm{a}$ & $2.886^{* * *}$ \\
\hline $50 \mathrm{~cm}$ & 24 & $4.88 \mathrm{~A}$ & 5 & $6.81 \mathrm{a}$ & 1.397 & $14.21 \mathrm{~A}$ & 13 & $26.52 \mathrm{a}$ & $1.867 * *$ \\
\hline
\end{tabular}

VMR-Variance: Mean Ratio, *** statistically significant differences from the theoretical value of 1 at $95 \%, 99 \%$ and $99.9 \%$ confidence level, respectively ( $T$-test)

***Štatisticky významné rozdiely od teoretických hodnôt 1 pre $95 \%, 99 \%$ a $99.9 \%$ intervaly spol’ahlivosti ( $T$-test)

$\dagger$ Comparison between non-meliorated and meliorated plot: $T$-test for mean comparison: values followed by the same capital letter are not significantly different $(\mathrm{P}<0.05) ; F$-test for variance comparison, variances followed by the same small letter are not significantly different $(P<0.05)$

†Porovnanir meliorovaných a nemeliorovaných variantov: $T$-test pre porovnanie priemerných hodnôt: Hodnoty nasledované tým istým vel'kým písmenom nie sú významne rozdielne $(P<0.05) ; F$-test pre porovnanie variancií; Hodnoty variancií nasledované tým istým malým písmenom nie sú významne rozdielne $(P<0.05)$.

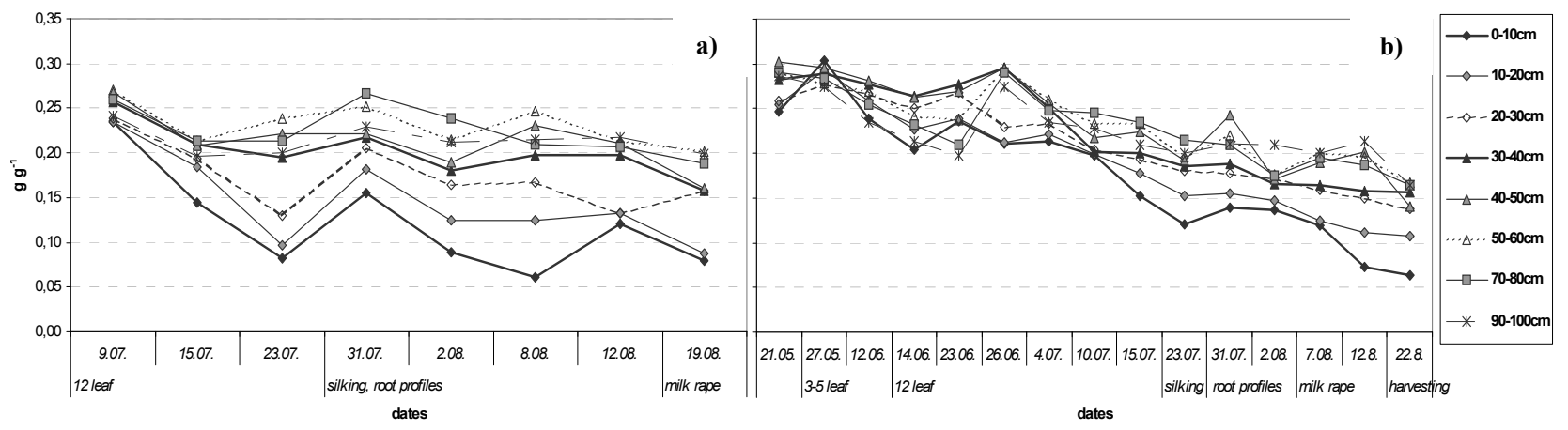

Fig. 5. Soil water content measured at different soil depths during the vegetation period of maize in a) non-meliorated and b) meliorated plots.

Obr. 5. Vlhkost' pôdy meraná v rozdielnych híbkach počas vegetačného obdobia kukurice; a) nemeliorovaný variant, b) meliorovaný variant.

\section{Correlation analyses}

Regarding the correlations between different root and soil parameters, dissimilar results were obtained for the two treatments. In the meliorated plot, the root density significantly correlated with the available soil water and the porosity (total and air-filled), and significantly but negative with the bulk density. In contrast, in the non-meliorated plot the root parameters correlated positively with the bulk density at sampling, but negatively with the porosity data. Looking at the correlation matrix (Tab. 4) one can recognize, that root density expressed as dry mass and percentage of squares consisting roots highly correlated with the hydraulic 
$\mathrm{T}$ a b 1 e 3. Crop characteristics and biomass production of maize on meliorated and non-meliorated plots.

$\mathrm{T}$ a b u l'k a 3. Charakteristiky porastov a produkcia biomasy kukurice na meliorovaných a nemeliorovaných variantoch.

\begin{tabular}{|c|c|c|c|c|c|}
\hline \multirow[t]{2}{*}{ Occasion (Stage) } & & \multicolumn{3}{|c|}{ At root observations (silking) } & \multirow{2}{*}{\begin{tabular}{|c|} 
Harvest \\
(milk-dough stage) \\
Biomass \\
fresh \\
{$\left[\mathrm{t} \mathrm{ha}^{-1}\right]$} \\
\end{tabular}} \\
\hline & $\begin{array}{l}\text { Plant density } \\
1000\left[\mathrm{pl} . \mathrm{ha}^{-1}\right]\end{array}$ & $\begin{array}{l}\text { Height } \\
{[\mathrm{cm}]}\end{array}$ & $\begin{array}{c}\text { Leaf area } \\
\text { green } \\
{\left[\mathrm{cm}^{2}\right] \text { per plant }}\end{array}$ & $\begin{array}{c}\text { Biomass } \\
\text { fresh } \\
{\left[\mathrm{t} \mathrm{ha}^{-1}\right]}\end{array}$ & \\
\hline No melioration & 91.3 & 141.9 & 2247 & 19.9 & 25.6 \\
\hline Melioration & 92.3 & 230.9 & 4056 & 44.5 & 48.0 \\
\hline
\end{tabular}

$\mathrm{T}$ a b 1 e 4. Coefficients of correlation estimated between root density and different soil parameters.

T a b u l'k a 4. Koeficienty korelácie medzi hustotou koreňov a rôznymi pôdnymi parametrami.

\begin{tabular}{|c|c|c|c|c|c|c|c|c|c|c|c|}
\hline & \multirow[b]{2}{*}{$\begin{array}{l}\text { Depth } \\
{[\mathrm{cm}]}\end{array}$} & \multirow{2}{*}{$\begin{array}{c}\text { Bulk } \\
\text { density* } \\
{\left[\mathrm{g} \mathrm{cm}^{-3}\right]}\end{array}$} & \multirow{2}{*}{$\begin{array}{c}\text { Available } \\
\text { water } \\
\text { [vol. \%] }\end{array}$} & \multirow{2}{*}{$\begin{array}{l}\text { Hydraulic } \\
\text { conductivity } \\
{\left[\mathrm{cm} \mathrm{d}^{-1}\right]}\end{array}$} & \multicolumn{2}{|c|}{ Porosity } & \multirow[b]{2}{*}{$\mathrm{pH}$} & \multirow[b]{2}{*}{$\begin{array}{l}\text { Clay } \\
{[\%]}\end{array}$} & \multicolumn{3}{|c|}{ Index } \\
\hline & & & & & $\begin{array}{c}\text { Total } \\
\text { [vol. \%] }\end{array}$ & $\begin{array}{c}\text { Air-filled } \\
\text { [vol. \%] }\end{array}$ & & & $\begin{array}{c}\mathrm{RMD} \\
{\left[\mathrm{mg} \mathrm{cm}^{-3}\right]}\end{array}$ & $\begin{array}{c}>0 \\
{[\%] \mathrm{Sq}}\end{array}$ & $\begin{array}{c}\text { Index }>4 \\
{[\%] \mathrm{Sq}} \\
\end{array}$ \\
\hline $\begin{array}{l}\mathrm{RMD}, \mathrm{mg} \mathrm{cm}^{-3} \\
\text { Index }>0,[\%]\end{array}$ & -0.910 & -0.590 & 0.557 & 0.785 & 0.061 & 0.300 & -0.755 & -0.744 & 1 & & \\
\hline $\begin{array}{l}\mathrm{Sq} \\
\text { Index }>4,[\%]\end{array}$ & -0.947 & -0.624 & 0.414 & 0.682 & 0.184 & 0.323 & -0.873 & -0.750 & 0.961 & 1 & \\
\hline$\underline{\mathrm{Sq}}$ & -0.779 & -0.484 & 0.644 & 0.811 & -0.079 & 0.235 & -0.558 & -0.655 & 0.954 & 0.837 & 1 \\
\hline
\end{tabular}

*Parameters measured at filed capacity level, RMD - root dry mass density, percentage of squares (Sq) consisting at least one root (Index $>0$ ) and a lot of roots (Index $>4$ ).

*Parametre merané pri vlhkosti pôdy na úrovni pol’nej vodnej kapacity; RMD - hustota suchej hmotnosti koreňov, percentuálne vyjadrenie ,štvorcov” (Sq) obsahujúcich aspoň jeden koreň (index $>0$ ) a viac koreňov (index $>4$ ).

conductivity, significant but negative with the clay content and the $\mathrm{pH}$ values at a certain soil depth. The strongest positive correlation ( $R=0.7$ to 0.8$)$ was estimated between the root (index and mass) density and the soil hydraulic conductivity, which can be assumed as an appropriate indicator for root growth distribution.

\section{Conclusions}

At the time of root observations at silking, a deeper allocation of the maize root density was observed down the soil profiles in the meliorated than in the non-meliorated plot. On the vertical planes, root densities, expressed as dry mass and proportion of "full" squares consisting at least one visible root were similar in the topsoil, but significantly higher in the subsoil of the meliorated plot. At the same time, the control plot showed frequent root grouping in areas with lower penetration resistance like pores and cracks at the top- subsoil boundary. The horizontal planes in the meliorated plot had more homogeneous root distribution with more "full" squares at all tested soil depths. In opposite, the control-planes generally had less "full" squares and large areas without roots and great distances for water and nutrient transmission in the soil. The spatial VMR test at $2 \mathrm{~cm}$ scale pointed to lack of root clustering only on the horizontal planes of the meliorated topsoil. At all other positions and scales examined, the VMR's were higher than 1.0 indicating different levels of clustering. Due to the root clustering and inter-roots competition, an inhibited water extraction from the subsoil was established in the control during the observed period, although the overall high plant available water estimated. The water reserves in the meliorated subsoil depleted more rapidly than those in the control. This was attributed to the faster plant growth and the more extensive root uptake there. At the same time, a delay in crop ontogenesis and a less biomass production was established in the non-meliorated plot. The strongest positive correlation was found between the root (mass and index) density and the soil hydraulic conductivity, which was assumed as a major root growth controlling factor in this case study. It can be further used as an appropriate indicator for root density distribution.

Acknowledgement. The authors thank the ÖFG, MOEL-Plus-Förderungsprogramm (Project 316) for the fellowship of Dr. M. Himmelbauer spent at "N. Poushkarov" Institute of Soil Science and Agroecology, Sofia, Bulgaria. 


\section{REFERENCES}

ALLEN R.G., PEREIRA L.S., RAES D., and SMITH M., 1998: Crop evapotranspiration- Guidelines for computing crop water requirements. FAO irrigation and drainage. Pap. No. 56, Rome.

AMATO M. and RITCHIE J.T., 2002: Spatial Distribution of Roots and Water Uptake of Maize (Zea mays L.) as Affected by Soil Structure. Crop Science, 42, 773-780.

ARVIDSSON J., 1999: Nutrient uptake and growth of barley as affected by soil compaction. Plant and Soil, 208, 9-19.

BADDELEY A., 2008: Analysing spatial point patterns in R. Workshop on Analysing Spatial Point Patterns. CSIRO and University of Western Australia. Workshop Notes, p. 199

BALDWIN J.P., TINKER P.B. and NYE P.H., 1972: Uptake of solutes by multiple root system from soil. II. The theoretical effects of root density and pattern on uptake of nutrients from the soil. Plant and Soil, 36, 693-708.

BENNIE A.T.P., 1996: Growth and mechanical impedance. In Plant Roots: The Hidden Half. Eds. Y. WAISEL, A. ESHEL and U. KAFKAFI. Marcel Dekker Inc., New York, USA, pp. 453-470.

BINGHAM I.J. and BENGOUGH A.G., 2003: Morphological plasticity of wheat and barley roots in response to spatial variation in soil strength. Plant and Soil, 250, 273-282.

BOYADGIEV T., 1994: Soil map of Bulgaria according to the FAO-UNESCO-ISRIC revised legend explanatory notes. Soil Science, Agrochemistry and Ecology, 4-6, 52-56.

CHOPART J.L. and SIBAND P., 1999: Development and validation of a model to describe root length density of maize from root counts on soil profiles. Plant and Soil, 214, 61-74,

DILKOVA R., FILCHEVA E., KERCHEV G., KERCHEVA M., 1998: Humus peculiarities of the virgin surface waterlogged soils. In Congres Mondial de Sci. du sol, 16e, Montpellier, France, 20-26 aout 1998. Resumes. Vol. 1, Symp. N 18, p. 378.

DROOGERS P., VAN der MEER F.B.W and BOUMA J., 1997: Water accessibility to plant roots in different soil structures occurring in the same soil type. Plant and Soil, 188, 83-91.

GEORGIEVA V., MOTEVA M., KAZANDJIEV V., 2007: Impact of Climate Change on Water Supply of Winter Wheat in Bulgaria. Agriculturae Conspectus Scientifi cus, Vol. 72, No. 1, 39-44.

GRIEG SMITH P., 1983: Quantitative Plant Ecology. Univ. of Calif. Press, Berkeley, p. 347.

HAKANSSON I. and LIPIEC J., 2000: A review of the usefulness of relative bulk density values in studies of soil structure and compaction. Soil \& Tillage Research, 53, 71-85.

HIMMELBAUER M.L., NOVÁK V., MAJERČÁK J., 2008: Sensitivity of soil water content profiles in the root zone to extraction functions based on different root morphological parameters. J. Hydrol. Hydromech., 56, 1, 34-44.

HORN R., AKKER VAN den J.J.H., ARVIDSSON J. (Eds.), 2000: Subsoil compaction. Distribution, Processes and Consequences, Adv. Geoecology, 32, 462 pp.

KOEDJIKOV H.A., 1975: The Root System of Cereal Plants. Publishing House of the Bulgarian Academy of Science, $581 \mathrm{pp}$.

KOLEVA E. and ALEXANDROV V., 2008: Drought in the Bulgarian low regions during the 20th century. Theoretical and Applied Climatology, Vol. 92, No.1-2, 113-120.
LABOSKI C.A.M., DOWDY R.H., ALLMARAS A.A. and LAMB J.A., 1998: Soil strength and water content influences on corn distribution in a sandy soil. Plant and Soil, 203, 239-247.

LIPIEC J., ARVIDSSON J., MURER E., 2003: Review of modelling crop growth ,movement of Chemicals in relation to topsoil and subsoil compaction. Soil \& Tillage Research, $73,15-29$.

NOVÁK V., 2003: Nutrients uptake by maize roots: vertical distribution of uptake rates during the vegetation period. J. Hydrol. Hydromech., 51, 1, 14-20.

PARDO A., AMATO M., CHIARANDA F.Q., 2000: Relationships between soil structure, root distribution and water uptake of chickpea (Cicer arietinum L.). Plant growth and water distribution. European Journal of Agronomy, 13, 39-45.

ROGERS A., 1974: Statistical Analysis of Spatial Distributions. Pion Ltd., London.

RUSSEL E.W. , 1980: Soil conditions and plant growth. Tenth Ed. Longman Group, UK Ltd., 849 pp.

SHOPSKI N., ILIEV K., DONEVA E., 1998: Management of surface waterlogged soils fertility by new ameliorative technology and systems. Soil Science, Agrochemistry and Ecology, 33, 2, 35-38.

TARDIEU F., 1988a: Analysis of the spatial variability of maize root density I. Effect of wheel compaction on the spatial arrangement of roots. Plant and Soil, 107, 259-266.

TARDIEU F., 1988b: Analysis of the spatial variability of maize root density II. Distances between roots. Plant and Soil, 107, 267-272

TARDIEU F., BRUCKLER L., and LAFOLIE F., 1992: Root clumping may affect the root water potential and the resistance to soil-root water on the uptake of ions by roots: I. Soil water content near a plane transport. Plant and Soil, 140, 291-301.

VOMOCIL J.A., 1965: Porosity. In: C.A. BLACK (Ed.): Methods of soil analyses. Part 1: Physical and Mineralogical Properties including Statistics of Measurement and Sampling. Agron. Monogr. 9, ASA and SSSA, Madison, WI, USA, pp. 299-314.

WULFSOHN D., GU Y., WULFSOHN A., MOJLAJ E.G., 1996: Statistical analysis of wheat root growth patterns under conventional and no-tillage systems. Soil \& Tillage Research, $38,1-16$

Received 26 February 2010 Accepted 23 June 2010

PRIESTOROVÉ ROZDELENIE KOREŇOV

A ODBER VODY KOREŇMI KUKURICE V PÔDE SO ZHUTNENOU PODORNIČNOU VRSTVOU

Margarita L. Himmelbauer, Willibald Loiskandl, Svetla Rousseva

Počas rastovej fázy metania $\mathrm{v}$ porovnaní s nemeliorovaným variantom bolo pre meliorovanú pôdu pozorované hlbšie rozloženie koreňov. Vo vertikálnej rovine, hustota koreňov vyjadrená hmotnost'ou suchých koreňov a podielom ,„plných" štvorcov - čo znamená výskyt aspoň jedného koreňa - bolo podobné $\mathrm{v}$ hornej vrstve pôdy pre oba varianty, ale koreňov bolo významne viac 
v podorničnej vrstve meliorovaného variantu. Súčasne, v „kontrolnom” variante sa vyskytovali zoskupenia koreňov na hranici medzi orničnou a podorničnou vrstvou, predovšetkým $\mathrm{v}$ póroch a puklinách. V horizontálnej rovine rezu meliorovaného variantu bolo pozorované relatívne homogénne rozdelenie koreňov s viacerými „plnými” štvorcami vo všetkých testovaných híbkach.

V protiklade s uvedeným, kontrolné varianty obsahovali menej ,plných” štvorcov a vel'ké plochy bez koreňov, teda vel'ké vzdialenosti pre prenos vody a živín $\mathrm{v}$ pôde. Priestorový test VMR v mierke $2 \mathrm{~cm}$ zdôraznil nedostatočné zhluky koreňov len $\mathrm{v}$ horizontálnych rovinách rezov meliorovanou orničnou vrstvou pôdy. $\mathrm{V}$ iných mierkach, ktoré boli aplikované, VMR boli vyššie ako 1,0, čo naznačuje rozdielne úrovne zhlukov. Pre tvorbu zhlukov koreňov a konkurenciu medzi ko- reňmi bol v kontrolnom variante znížený odber vody koreňmi z podorničnej vrstvy, hoci bol $\mathrm{v}$ nej zistený dostatok vody dostupnej rastlinám. Zásoby vody $\mathrm{v}$ meliorovanej pôde sa vyčerpali rýchlejšie, ako tie v kontrolnom variante. Je to zrejme dôsledok rýchlejšieho rastu rastlín a teda vyšších intenzít odberu vody. Súčasne, $\mathrm{v}$ porovnaní s meliorovanou pôdou, $\mathrm{v}$ kontrolnom variante bola pozorovaná pomalšia ontogenéza a nižšia produkcia biomasy. Najvýraznejšia pozitívna korelácia bola zistená medzi hustotou koreňov (hmotnost' a index) a hydraulickou vodivost'ou pôdy, ktorá bola považovaná $\mathrm{v}$ tejto štúdii za hlavný faktor regulujúci rast koreňov. Bude sa aj nad'alej používat' ako vhodný indikátor rozdelenia hustoty koreňov. 